\title{
Resource use efficiency and profitability of fluted pumpkin production in Ukwuani local government area of Delta State, Nigeria
}

\author{
Ogisi O’raye Dicta, Begho Toritseju*, Ewolor Scholastica Agatha \\ Department of Agricultural Economics and Extension,. Delta State University, Asaba Campus, Asaba. Nigeria \\ Email address: \\ tbegho@yahoo.com (B. Toritseju) \\ To cite this article: \\ Ogisi O'raye Dicta, Begho Toritseju, Ewolor Scholastica Agatha. Resource Use Efficiency and Profitability of Fluted Pumpkin \\ Production in Ukwuani Local Government Area of Delta State, Nigeria. American Journal of Agriculture and Forestry. \\ Vol. 2, No. 4, 2014, pp. 129-134. doi: 10.11648/j.ajaf.20140204.15
}

\begin{abstract}
The paper examined resource-use and profitability of fluted pumpkin (Telfaria occidentalis Hook F. Cucurbitaceae) production in Ukwuani local Government Area of Delta State, Nigeria. Primary data were obtained from questionnaire administered to 140 fluted pumpkin farmers drawn using systematic sampling techniques from the study area. Data were analyzed using descriptive statistics, marginal value productivity, multiple regression and a 5-point likert scale. Results showed that most of the respondents were females, illiterate and married. Farmers operated on subsistence level, about $95 \%$ practiced mixed cropping with farming experience not less than 5 years. An adjusted $\mathrm{R}^{2}$ value of 0.664 indicated that the independent variables; farm size, labour and quantity of seed in the model explained $66 \%$ of variations in the dependent variable (output). The F value of 60.09 showed the overall statistical significance with a $P$ value of zero. Net return per hectare was $\$ 644.90$. The benefit-cost ratio was $\$ 1$ to $\$ 1.23$ which implies that for every $\$ 1$ invested, 23 cents was obtained thus depicting that the enterprise was profitable in the study area. Resources under-utilized were quantity of seed and farm size while family and hired labour were over-utilized. Major constraints faced by farmers were; high cost of labour, lack of adequate and quality seeds, pests and disease attack, storage and transportation cost. It is recommended that effective agricultural extension services, credit and loan schemes and infrastructure should be provided to farmers in the study area for increased profitability, yield and resource-use efficiency of fluted pumpkin production.
\end{abstract}

Keywords: Efficiency, Fluted Pumpkin, Profitability, Resource Use

\section{Introduction}

Fluted pumpkin (Telfaria occidentalis Hook F. Cucurbitaceae) is the first in the indigenous vegetable crops priority rating of south-eastern Nigeria. This is in accordance with the preference of farmers, researchers and extension agents. It is one of the most important vegetable in Nigeria referred to as "Ugwu" in Igbo, "Iroko" in Yoruba and "Umee" in Urhobo.

Telfaria occidentalis is a leafy vegetable (Enabulele \& Ilavbarhe, 2001) an important component of the traditional farming systems and daily diet of Nigerians (Akoroda, 1990) mainly grown for its highly nutritive value. Consumers of fluted pumpkin have increased tremendously over the years, reason for this increase and acceptance is that the seeds, shoots, leaves and stem are consumed as food for man and fodder for animals.
Fluted pumpkin is perennial when grown on well-drained soils, slightly shaded and mulched but not so soggy soils (Idowu, Alimi, Tijani \& Okobi, 2007). In the study area, the crop is grown on poor soils as an annual during the rainy season and also during the dry season around rivers or water sources. It is grown along side crops such as yam, melon, pepper and cassava.

Fluted pumpkin is very important in the diet of children, men, women, nursing mothers as well as livestock due to its high nutritive value. But in Nigeria, the output has not been able to meet the demand for human food not to mention that of livestock feed. As a result of the growing need, the task of producing enough fluted pumpkin poses an increasing challenge.

In Ukwuani Local Government area, fluted pumpkin plays an important role not only as the major source of vitamins in diets but also as a source of livelihood for the majority of farmers who grow and sell this vegetable. 
Efficiency of resource use is a very fundamental strategy that leads to increased productivity. The inability of farmers to combine resources efficiently with other factors such as price and non-price factors affect real farm profit (Kwanashie, Garba \& Ajilimar, 1997). This study was conducted to isolate the factors that affect profitability and determine their effect on the production of fluted pumpkin in the study area. The broad objective of the study therefore was to evaluate resource-use efficiency and profitability of fluted pumpkin (Telfaria occidentalis Hook F. Cucurbitaceae) production in Ukwuani Local Government Area of Delta State. The specific objectives were to: determine cost and benefit of fluted pumpkin in the study area, examine the resource-use efficiency in fluted pumpkin production, factors affecting production of fluted pumpkin and identify production constraints to fluted pumpkin.

Several studies in Nigeria have been carried out to analyse resource-use efficiency as well as profitability of crops and more specifically vegetables.

Udoh \& Akpan, (2011) in their study estimated the efficiency of resource use among urban vegetable (Talinium triangulare) farmers in Akwa Ibom State. They reported showed that waterleaf farmers were inefficient in the use of these resources with land and manure was underutilized, while labour was over utilized. In terms of profitability, Udoh \& Akpan, (2011) reported that farmers made profit of $\$ 1765.53$ per hectare.

In studying resource use efficiency and profitability, several methods have been widely adopted. Ala (2013) examined of profitability and resource-use efficiency of yam production by women in Bosso Local Government Area of Niger State, Nigeria using farm budgeting, multiple regression and MVP/MFC ratio. The result of Ala (2013) showed that farmers obtained a net profit of $\$ 63.39 /$ ha and the MVP/MFC ratio test revealed that farm size, fertilizers and farm labour were underutilized by the farmers. Similarly, Omonona et al., (2011) in their study on profitability and resource-use efficiency among ofada rice farmers in southwest, Nigeria adopted the Marginal value product (MVP) approach and found that all identified resources were underutilize.

Jirgi, Ogundeji, Viljoen \& Adiele, (2010) examined the profitability and resources-use efficiency of millet/cowpea mixed farmers production in Niger state Nigeria using the farm budgeting technique and exponential production function technique. The results showed that the estimated gross margin, net farm income, was $\$ 353.67$ per hectare, while the results of allocative efficiency show that seeds, family labour and agrochemicals were under-utilized.

More specifically, Ayinde, Akerele, \& Ojeniyi, (2007); Idowu, Alimi, Tijani \& Okobi, (2007) examined economic factors affecting the production for fluted pumpkin using a modified cost-route approach and regression analysis. They reported fluted pumpkin production as being profitable under existing production systems with an average net income of \$205.90/ha on a mean farm size of 0.301 ha. Cost of fertilizer and farm size were however underutilized.
Regarding constraints faced by fluted pumpkin farmers, Nwosu, Onyeneke \& Okoli, (2012) reported that lack of credit facilities, lack of availability of inputs, pests and disease infestation, inadequate information about input and output prices, and poor road network respectively.

\section{Methodology}

\subsection{The Study Area}

The study was carried out in Ukwuani Local Government Area of Delta State, Nigeria. The study area was selected for this research because a considerable quantity of fluted pumpkin is produced and marketed in this area. Ukwuani Local Government Area shares boundaries with Ndokwa West in the East, Ethiope-East in the south and Orhionwhon Local Government area of Edo state in the North. It lies approximately between longitude $4.5^{0} 6.3^{0} \mathrm{~W}$ and latitude $5.5^{0} 30^{\circ} \mathrm{N}$ of the equator. The climate is tropical, marked by two distinct seasons; wet and dry with an average temperature of $30^{\circ} \mathrm{C}$. The inhabitants engage in farming and crops commonly grown in the area are fluted pumpkin, melon, sweet pepper, cassava, yam and maize.

The local Government Area consists of ten communities. Out of these, four contiguous communities were purposively selected for the study. Each of these communities was visited and a list of farmers that cultivated fluted pumpkin above subsistence level was made to form the working sample frame. Systematic sampling was applied to draw at least 35 farmers from each community. This resulted in a total sample size of 140 . Primary data were collected using copies of well-structured questionnaires which were administered to respondents within a time frame of July 2013 to January 2014. Cost-benefit analysis was done to determine the cost and benefit of fluted pumpkin in the study area, the relationship between marginal value productivity (MPV) and marginal factor cost (MFC) was used to examine the resource-use efficiency in fluted pumpkin production while multiple regression analysis was used to determine factors affecting production of fluted pumpkin in the study area.

\subsection{Model Specification}

Cost Benefit analysis was calculated as: $\mathrm{BCR}=\mathrm{TR} / \mathrm{TC}$

\subsection{Multiple Regression}

Multiple regression was used to express causal relationship between the dependent variable (Yield output of fluted pumpkin) and the independent variables. Four functional forms were tried and the model with best fit was taken as the lead equation.

$\mathrm{Y}=\mathrm{f}\left(\mathrm{X}_{1}, \mathrm{X}_{2}, \mathrm{X}_{3}, \mathrm{X}_{4}, \mathrm{X}_{5}, \mathrm{X}_{6}, \mu\right)$

Linear Function

$\mathrm{Y}=\mathrm{b}_{0}+\mathrm{b}_{1} \mathrm{X}_{1}+\mathrm{b}_{2} \mathrm{X}_{2}+\mathrm{b}_{3} \mathrm{X}_{3}+\mathrm{b}_{4} \mathrm{X}_{4}+\mathrm{b}_{5} \mathrm{X}_{5}+\mathrm{b}_{6} \mathrm{X}_{6}+\mu$

Exponential Function 
$\log Y=b_{0}+b_{1} X_{1}+b_{2} X_{2}+b_{3} X_{3}+b_{4} X_{4}+b_{5} X_{5}+b_{6} X_{6}+\mu$ Semi Log Function

$\mathrm{Y}=\mathrm{b}_{0}+\mathrm{b}_{1} \log \mathrm{X}_{1}+\mathrm{b}_{2} \log \mathrm{X}_{2}+\mathrm{b}_{3} \log \mathrm{X}_{3}+\mathrm{b}_{4} \log \mathrm{X}_{4}+$ $\mathrm{b}_{5} \log \mathrm{X}_{5}+\mathrm{b}_{6} \log \mathrm{X}_{6}+\mu$

Double-Log Function

$\log Y=b_{0}+b_{1} \log X_{1}+b_{2} \log X_{2}+b_{3} \log X_{3}+b_{4} \log X_{4}+$

$b_{5} \log X_{5}+b_{6} \log X_{6}+\mu$

Where:

$\mathrm{Y}=$ Quantity of fluted pumpkin produced in land area

$\mathrm{X}_{1}=$ Farm size

$\mathrm{X}_{2}=$ Family labour (Man days)

$\mathrm{X}_{3}=$ Hired Labour (Man days)

$\mathrm{X}_{4}=$ Quantity of seeds $(\mathrm{kg})$

$\mathrm{X}_{5}=$ Quantity of fertilizer $(\mathrm{kg})$

$\mathrm{X}_{6}=$ Quantity of Herbicides $(\mathrm{kg})$

$\mu=$ stochastic error term

\section{Marginal Value Product and Marginal Factor cost}

$\mathrm{MVP}=\operatorname{MPP} \mathrm{X} \mathrm{P}_{\mathrm{y}}$

Where:

MVP = Marginal value product

MPP = Marginal physical product

$\mathrm{P}_{\mathrm{y}}=$ Unit price of output of fluted pumpkin When

$\frac{M V P}{M F C}>1$ The resource use is below Optimum

(under-utilization)

$\frac{M V P}{M F C}<1$ The resource use is above Optimum

(over-utilization)

$\frac{M V P}{M F C}=1$ The resource use is at Optimum

(Optimum-utilization)

\section{Results and Discussions}

\subsection{Socioeconomic Characteristic of Respondents}

The socioeconomic characteristic of respondents are as presented in Table 3.1. The results showed that majority of respondents were female and within the age group of $41-$ 50. About 78 percent of the farmers were married with an average household size of 5 persons. This implies that pumpkin farmers were within the ages regarded as economically productive in a population. About 53\% had no education, $28 \%$ had primary education, $12 \%$ had secondary education while only $2 \%$ had tertiary education. This implies that a high percentage of pumpkin farmers are illiterate Majority (73\%) of the farmers had above 5 years of farming experience and about $95 \%$ of them practiced mixed or intercropping. Crops intercropped with fluted pumpkin were maize, yam, cassava and pepper. The years of experience and wealth of knowledge of the farmers have some impact on the management ability and influences output. Most of the farmers which accounted for $80 \%$ cultivated 1.0ha and below thus output was small and fragmented. Olayide, et al., (1980) classified small scale farmers as those having 0.1-5.9ha farm size. Since land is a very important fixed asset, its method of acquisition is crucial. It was observed that inheritance (72\%) was the common method of land ownership in the study area. Others were through rent, purchase and shared cropping.

Table 3.1. Socioeconomic Characteristics of Respondents

\begin{tabular}{|c|c|c|}
\hline Characteristics & Frequency & Percentage \\
\hline \multicolumn{3}{|l|}{ Age (Years) } \\
\hline$<30$ & 6.0 & 4.3 \\
\hline $31-40$ & 46.0 & 32.9 \\
\hline $41-50$ & 71.0 & 50.7 \\
\hline$>50$ & 17.0 & 12.1 \\
\hline \multicolumn{3}{|l|}{ Educational Level } \\
\hline No formal education & 81.0 & 57.9 \\
\hline Primary & 39.0 & 27.9 \\
\hline Secondary & 17.0 & 12.1 \\
\hline Tertiary & 3.0 & 2.1 \\
\hline \multicolumn{3}{|l|}{ Gender } \\
\hline Male & 59.0 & 42.1 \\
\hline Female & 81.0 & 57.9 \\
\hline \multicolumn{3}{|l|}{ Marital status } \\
\hline Single & 4.0 & 2.8 \\
\hline Married & 109.0 & 77.9 \\
\hline Widowed & 27.0 & 19.3 \\
\hline \multicolumn{3}{|l|}{$\begin{array}{l}\text { Farming Experience } \\
\text { (Years) }\end{array}$} \\
\hline$<1$ & 0.0 & 0 \\
\hline $1-5$ & 28.0 & 20 \\
\hline $6-10$ & 66.0 & 47.2 \\
\hline$>10$ & 46.0 & 32.8 \\
\hline \multicolumn{3}{|l|}{ Cropping pattern } \\
\hline Sole & 7.0 & 5 \\
\hline Mixed & 133.0 & 95 \\
\hline \multicolumn{3}{|l|}{ Farm size } \\
\hline$<0.5$ & 36.0 & 25.7 \\
\hline $0.5-1.0$ & 77.0 & 55 \\
\hline $1.1-2.0$ & 27.0 & 19.3 \\
\hline
\end{tabular}

\subsection{Cost and Benefit Analysis}

Labour cost: The unit cost of hired labour per man-day in the study area was $\$ 4.30$ and the average number of man-days per hectare utilized in the study area was $\$ 0.82$ as shown in Table 3.2. Labour cost accounted for $98.5 \%$ of the total variable cost.

Seed Cost: On an average, seeds from four pods of fluted pumpkin were used per hectare. The average cost of a pod was $\$ 1.54$ thus average cost of seeds per hectare was $\$ 6.15$. Seed cost accounted for $1.5 \%$ of the total variable cost.

Fertilizer and Herbicide cost: None of the respondents applied fertilizer and or herbicides on their farms therefore, cost of fertilizer was not included.

Cost of Land Rentage: The average cost of rent was $\$ 18.44$ per hectare. Majority of farmers used inherited land which was valued at the rent value in the study area. This accounted for $63 \%$ of the total fixed cost. 
Table 3.2. Average Cost of Production for Fluted Pumpkin in the Study Area

\begin{tabular}{llll}
\hline Input cost (\$) & Quantity & $\begin{array}{c}\text { Unit } \\
\text { cost }\end{array}$ & Total \\
\hline Variable input & & \\
Labour (Man-Days) & 0.69 & 4.30 & 486.17 \\
Seeds (pods) & 0.02 & 1.54 & 6.15 \\
Total Variable Cost (A) & & 492.32 \\
Fixed Inputs & & \\
Cutlasses & & 7.38 \\
Hoes & & 3.69 \\
Files & & 0.92 \\
Land rent (ha) & & 18.44 \\
Total Fixed cost (B) & & 30.42 \\
Total cost (A+B) & & 522.74 \\
\hline
\end{tabular}

\subsection{Fixed Costs}

The cost of each hectare was calculated using the straight line depreciation method. For the purpose of this study, a salvage value of zero (0) was assumed. The average life span of land was insurmountable only its nutrients can depreciate but for farming implements it was about three years.

Table 3.3. Relative cost of Variable Inputs

\begin{tabular}{lll}
\hline Variable input & Variable cost (\$) & Percent distribution \\
\hline Labour & 486.17 & 98.75 \\
Seed & 6.15 & 1.25 \\
Total & $\mathbf{4 9 2 . 3 2}$ & $\mathbf{1 0 0}$ \\
\hline
\end{tabular}

\subsection{Gross Return}

Gross return per hectare for a farmer on the average was $\$ 644.90$ thus Net profit on the average amounted to $\$ 122.16$.

The Benefit Cost Ratio (BCR) of 1.23 was obtained. By implication of this criterion for selection of enterprise, if BCR is greater than 1, the business enterprise is viable and profitable. As such, fluted pumpkin production is profitable in the study area.

Table 3.4. Relative Shares of Total Variable Cost and Total Fixed Cost

\begin{tabular}{lll}
\hline Cost & Shares (\$) & Relative percent \\
\hline Total Variable cost & 492.32 & 94.2 \\
Total fixed cost & 30.42 & 5.8 \\
Total & $\mathbf{5 2 2 . 7 4}$ & $\mathbf{1 0 0}$ \\
\hline
\end{tabular}

\subsection{Percentage Gain Per Hectare}

The percentage gain per hectare is $0.23(23 \%)$. This implies that for every $\$ 1.00$ spent in production, there is return of 23 cents. This is similar to the findings of Idowu, Alimi, Tijani \& Okobi, (2007) who reported that fluted pumpkin was profitable under existing production systems with an average net income of $\$ 205.90 /$ ha on a mean farm size of 0.301 ha.

Table 3.5. Cost and Return per hectare of fluted Pumpkin

\begin{tabular}{ll}
\hline Gross Return per ha & $\mathbf{6 4 4 . 9 0}$ \\
\hline Total variable cost & $(492.32)$ \\
Total fixed cost & $(30.42)$ \\
Net Return/ha & $\mathbf{1 2 2 . 1 6}$ \\
\hline
\end{tabular}

\subsection{Factors affecting Output of Fluted Pumpkin}

The production function for this study was estimated using four functional forms. The linear form was chosen as the lead equation thus was further discussed. An Adjusted $\mathrm{R}^{2}$ of 0.664 implies that about $66 \%$ of the variation in output was explained by the independent variables. Farm sizes, family labour and quantity of seeds were significant at $\mathrm{P}<0.05$. It therefore implies that output can be increased to some extent by increasing these significant independent variables.

Table 3.6. Factors affecting Output of Fluted Pumpkin

\begin{tabular}{llll}
\hline Variable & Coefficient & T-statistics & P-value \\
\hline Farm size & 27.000 & 1.775 & $0.010^{*}$ \\
Family Labour & 3.595 & 0.974 & $0.028^{*}$ \\
Hired Labour & -0.072 & 0.005 & 0.067 \\
Quantity of seed & 13.435 & 3.064 & $0.005^{*}$ \\
$\mathrm{R}^{2}$ & 0.673 & & \\
Adjusted R & 0.664 & & \\
F-Cal & 60.095 & & \\
\hline
\end{tabular}

* Significant at $\mathrm{P}<0.05$

\subsection{Resource-Use Efficiency}

Marginal value productivity analysis was used to determine the efficiency with which each variable was used. Results as shown in Table 3.7 show that labour (family and hired) was over utilized while farm size and quantity of seeds were under-utilized. This suggests thus a wider scope for improvement by reallocating resources optimally in order to reduce waste and maximize output.

Table 3.7. Efficiency Analysis of Variable inputs

\begin{tabular}{|c|c|c|c|c|c|}
\hline Variable & Coefficient & MFC & MVP & MVP/MFC & Efficiency status \\
\hline Farm size & 27.000 & 18.44 & 580.41 & 31.478 & Under-utilized \\
\hline Family Labour & 3.595 & 4.30 & 2.88 & 0.681 & Over-utilized \\
\hline Hired Labour & -0.072 & 4.30 & 0.06 & -0.041 & Over-utilized \\
\hline Quantity of seeds & 13.435 & 1.54 & 866.42 & 563.867 & Under-utilized \\
\hline
\end{tabular}




\subsection{Constraints of Fluted Pumpkin in the Study Area}

The mean ranking for each identified constraint was calculated and the most serious ones were determined by the mean score of 2.5. From the study, unpredictable market, high cost of labour, problem of storage and land acquisition, seed scarcity, lack of equipment and high cost of transportation were serious constraint to fluted pumpkin production in the study area.

Table 3.8. Constraints of fluted Pumpkin in the Study Area

\begin{tabular}{llllllll}
\hline Challenges & \multicolumn{2}{l}{ Ranking } & & & & Product of respondents & $\begin{array}{l}\text { Mean } \\
\text { ranking }\end{array}$ \\
\hline High cost of Labour & 5 & 4 & 3 & 2 & 1 & & $3.23^{*}$ \\
Labour scarcity & 10 & 48 & 2 & 35 & 2 & 323 & $3.11^{*}$ \\
Problem of Land acquisition & 6 & 46 & 1 & 49 & 0 & 311 & $3.69^{*}$ \\
Problem of storage & 1 & 82 & 5 & 9 & 3 & 369 & $3.23^{*}$ \\
High cost of Transportation & 6 & 21 & 63 & 10 & 0 & 323 & $3.61^{*}$ \\
Seed scarcity & 1 & 74 & 11 & 13 & 1 & 361 & $3.59^{*}$ \\
Inadequate Finance & 0 & 77 & 5 & 18 & 0 & 359 & 1.97 \\
\hline
\end{tabular}

\section{Conclusion}

We find that most of the respondents were females, illiterate and married. Farmers operated on subsistence level, about $95 \%$ practices mixed cropping with farming experience not less than 5 years. An adjusted $\mathrm{R}^{2}$ value of 0.664 indicated that the independent variables; farm size, labour and quantity of seed in the model explained $66 \%$ of variations in the dependent variable (output). Net return per hectare was $\$ 644.90$. The benefit-cost ratio was $\$ 1$ to $\$ 1.23$ thus it could be said that the enterprise was profitable in the study area. Resources under-utilized were quantity of seed and farm size while family and hired labour were over-utilized. Further, it was established that constraints faced by farmers were; high cost of labour, lack of adequate and quality seeds, pests and disease attack, storage and transportation cost.

From the results obtained, we make the following recommendation: provision of improved seeds and encourage fertilizer use, training of farmers on method to avoid waste in order that resources are put to optimum use. Also efforts should be made to provide credit and loan facilities to farmers to ease financial and capital constraints while improvement in infrastructural facilities will better the socioeconomic status of farmers.

\section{Acknowledgements}

The authors wish to acknowledge the enumerators and anonymous referees who read through the manuscript.

\section{References}

[1] Akoroda, M.O "Ethnobotany of Telfaria occidentalis Hook. F. (Cucurbitaceae) among Ibos of Nigeria". Economic Botany 44(1) 29-30. 1990.
[2] Ala, A. L. "Determination of Profitability and Resource-use Efficiency of Yam Production by Women in Bosso Local Government Area of Niger State, Nigeria”. European Scientific Journal, 9(16). 2013.

[3] Ayinde, I. A., Akerele, D. and Ojeniyi, O. T. "Resource use ef ciency and profitability of fluted pumpkin production under tropical conditions". International Journal of Vegetable Science, 17(1), 75-82. 2010.

[4] Enabulele, H.N and Ilavbarhe K.O "A trend in the Analysis of the Production of some Horticultural Crops in Nigeria". Nigerian Journal of Horticultural Sciences (NJHS), May 2001, 5 (1): 1-9. 2001.

[5] Idowu, E.O, T. Alimi, A. Tijani and C.N. Okobi. "Profitability and Resource Use Efficiency of Fluted Pumpkin". International Journal of Vegetable science. Vol 13, Issue 1. 2007.

[6] Idowu, E. O., Alimi, T., Tijani, A. A., \& Okobi, C. N. "Profitability and resource use efficiency in fluted pumpkin.” International Journal of Vegetable Science, 13(1), 73-84. 2007.

[7] Jirgi, A. J., Ogundeji, A. A., Viljoen, M. F., \& Adiele, M. A. "Resource Use Efficiency of Millet/Cowpea Intercropping in Niger State, Nigeria." In Joint $3^{\text {rd }}$ African Association of Agric. Econs.(AAAE) and $48^{\text {th }}$ Agric. Econs. Asso. of South Africa (AEASA) conference at Cape Town South Africa Sept 19-23. 2010.

[8] Kwanashie, M.A, Garba A. and Ajilimar A., "Policy Modelling in Agriculture. Testing the respose of Agriculture to Adjustment Policies in Nigeria". African Economic Research-Consortium, Research paper 57. 1997.

[9] Nwosu, C. S., Onyeneke, R. U., and Okoli, V. B. N. "Socio-economic determinants of fluted Pumpkin leaf (telferia occidentalis) production in Ezinihitte Mbaise local government area of Imo state, Nigeria". Agricultural Science Research Journal, 2(6), 355-361. 2012.

[10] Olayide, S.O., Eweke, J.A. and Bello-Osagie, V.E. (Eds). "Nigerian Small farmers. CARD University of Ibadan, for Benin-Owena River Basin Development Authority, Benin City". 1980. 
[11] Omonona, B. T., Lawal, J. O., Oyebiyi, I. D., Tenywa, J. S., Taulya, G., Kawube and Santos, L. "Profitability and resource-use efficiency among Ofada rice farmers in southwest, Nigeria". In 10th African Crop Science Conference Proceedings, Maputo, Mozambique, 10-13 October 2011. (pp. 69-71). African Crop Science Society. 2011.
[12] Udoh, E. J., and Akpan, S. B. Measuring technical efficiency of water leaf (Talinum triangulare) production in Akwa Ibom State, Nigeria. American-Eurasian Journal of Agriculture and Environmental Science, 2(5), 518-522. 2007. 